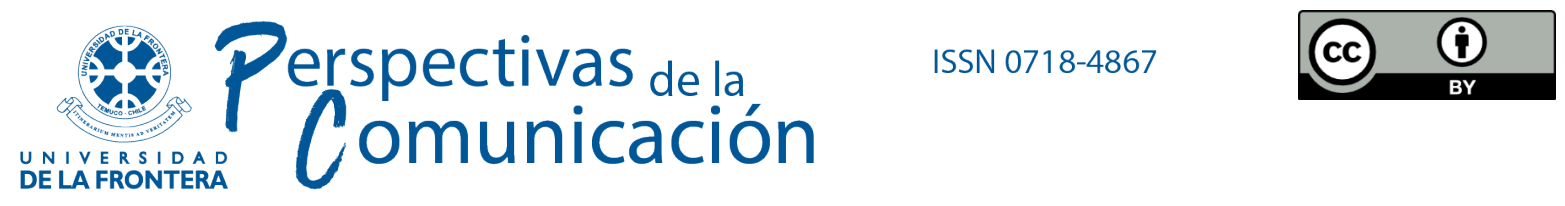

Article

\title{
GODMOTHERS: NARRATIVE PORTRAITS FROM THE PAST OF TWO DISTINCT CAMORRA WOMEN
}

DOI: POR ASIGNAR

\author{
Dra. Silvia Pezzoli \\ Universidad de Florencia, Florencia, Italia \\ silvia.pezzoli@unifi.it \\ ORCID iD: https://orcid.org/oooo-0002-3958-1450 \\ Dra. Beatriz Peña Acuña \\ Universidad de Huelva, Huelva, España \\ beatriz.pa@dfilo.uhu.es \\ ORCID iD: https://orcid.org/o000-0002-0951-795X
}

Recibido el 2020-03-28

Revisado el 2020-10-29

Aceptado el 2020-10-29

Publicado el 2021-09-21

\begin{abstract}
In recent years, we have seen a significant increase in television series productions featuring female leads, including bloodthirsty women who commit cruel crimes and order massacres. Given that traditional gender expectations see femininity associated to stereotypes such as care and caring for others, with emotion, passivity and vulnerability and, instead, violence and aggression as something intrinsic to the conceptualization of masculinity, the theoretical starting premise is that the narratives that portray violent women commit themselves to a problematic relationship with one of the pillars of male domination, that of violence. The aim of this study is to analyze two real women from the Camorra, Pupetta and Rosetta, represented in two films: The Challenge ( $L a$ sfida) by Francesco Rosi (1958) and The Professor (Il camorrista) by Giuseppe Tornatore (1986) to investigate the nascent state of this troubled relationship.
\end{abstract}

Keywords: Antiheroine, violence, woman, gender representation, male domain. 


\title{
MADRINAS: RETRATOS NARRATIVOS DEL PASADO DE DOS MUJERES DISTINTAS DE LA CAMORRA
}

\begin{abstract}
Resumen
En los últimos años, hemos visto un aumento significativo en las producciones de series de televisión que proponen protagonistas femeninas y, entre ellas, mujeres sedientas de sangre que cometen crímenes crueles y ordenan masacres. Dado que las expectativas de género tradicionales ven la feminidad asociada a estereotipos con el cuidado y el cuidado de los demás, con la emoción, la pasividad y la vulnerabilidad y, en cambio, la violencia y la agresión como algo intrínseco a la conceptualización de la masculinidad, la premisa teórica de partida es que las narraciones que retratan a las mujeres violentas se comprometen a una relación problemática con uno de los pilares de la dominación masculina, el de la violencia. El objetivo de estudio es analizar a dos mujeres reales de la Camorra, Pupetta y Rosetta, representadas en dos filmes: El reto (La sfida) de Francesco Rosi (1958) y El camorrista (Il camorrista) de Giuseppe Tornatore (1986) para investigar el estado naciente de esta relación problemática.
\end{abstract}

Palabras clave: anti-heroína, violencia, mujer, representación de género, dominio masculino. 


\section{Introduction}

While we try to avoid crime and violence in our personal lives, most of us enjoy danger at a safe distance. There is nothing more compelling than crime and violence if we are not subject to direct physical harm. The mass media entertains us with violence and crime as a form of daily cultural consumption, due to the invisible buffer provided by the medium itself, which allows us to satisfy our carnal curiosities from a safe space.

Contemporary Western society has a complex relationship with violence. Our society disapproves of and 'expropriates' violence as Giddens (1990) states, but as Thompson (1995) explains, society discovers and recovers violence through the media. So, it is not surprising that crime and violence 'are at home' in the media. When crimes are committed by women, they become even more interesting, since they are a challenge against our society's behavioural standards and expectations. This is probably the reason why in the last several years there has been a surprising proliferation of TV series featuring female protagonists committing various types of crimes (Negra \& Lagerwey, 2017). Bloodthirsty women are dominating the screens of our televisions, computers, and tablets, thus creating both a rejection and denial of the crimes being committed and simultaneously producing a sense of satisfaction from challenging the social order. Through these representations of women in crime, we experience crossing the borders of what is socially accepted. Violence and crime are often solely male domains, and as Milly Buonanno states in her edited collection Television Antiheroines (2017), these multiple images of bad women in TV productions serve to challenge male domination (Bourdieu, 2002). While violent women may be frequently represented in TV series, the same trend does not apply to the film industry, which appears to be lagging in the number of antiheroines featured.

Television serial productions encourage experimentation, which could be the reason why more antiheroines are found in that medium, since representations of violent women are still not always socially accepted. Many authors assert that media outlets are often asked to limit the quantity and quality of violent women protagonists because they challenge everyday reality and the public's subconscious expectations of female behaviour (Morrissey, 2003; Boyle, 2005; Jewkes, 2011). Such unrealistic proportions of violent women in TV series and in cinema might have more to do with the different kinds of audiences these two media have: a curious, topic-related, younger and active audience for serial TV and a cinematic audience now 'residual' in the sense that it comprises people unfamiliar with new 
technologies for online/streaming consumption and therefore perhaps more conservative in terms of gender order-related representations.

Nevertheless, the aim of this article is to analyze the way in which two antiheroines have been depicted in two different films and whether those narratives have a problematic relationship with that pillar of male domination: violence (Bourdieu, 2002). We have chosen La sfida (The Challenge) by Francesco Rosi (1958) and Il camorrista (The Professor) by Giuseppe Tornatore (1986), to investigate the origin of this problematic relationship, since these films depict two important women of the Camorra. The Camorra is a specific Italian Mafia organization based in Naples (homologue to the Sicilian Cosa Nostra, to Calabrian 'Ndrangheta, to Apulian Sacra Corona Unita), and both films are based on actual events, real individuals, journalistic reports and judiciary facts. The Camorra boss Assunta Maresca, known as 'Pupetta' (little doll), is the featured female (anti)heroine in La sfida, while Rosetta Cutolo, sister of the Camorra boss Raffaele Cutolo, is the (anti)heroine of Il camorrista. (Here 'anti' is bracketed since the two movies do not depict them as the violent women they were in real life.) The two cinematic texts give different representations of the Camorra women and, in this study, we question whether they could challenge the gender order. More specifically, this article analyses the correspondences between the filmic representations and the traditional roles played by women in Mafia organizations, i.e. the Camorra organization. Secondly, this article explores the gender construction strategies used in La sfida and Il camorrista. Lastly, this contribution aims to open a dialogue on how filmic representations differ from those found in journalistic sources and also - recommended areas for future study - those of law and the critical history of cinema, all traditionally characterized by a male gaze.

Although in Western countries there has been an increase in the number of murders committed by women, the gap between male and female homicides is still considerable. Furthermore, the gap between crimes committed by women and crimes committed by men is widening in relation to the increasing gravity and ferocity of the crime. In Italy, the proportion of women out of the total number of people arrested or reported for homicide was 9.1 percent in 2016 (Barbagli \& Minello, 2018). Crimes committed by women are usually based on domestic and intimate ties. These are crimes of jealousy or acts of violence involving partners and children or tied to conflicts over family inheritance disputes. Female crimes outside the domestic sphere and, consequently, capable of challenging patriarchal norms, are very few (Seal, 2010; O'Neall \& Seal, 2012). Women in criminal organizations 
represent an exception to the rule. In fact, although it is difficult to understand their actual degree of autonomy, it is true that the Mafia and the Camorra women often become bosses of a specific public domain, even if they often act in a man's stead. In this way, they represent a double deviancy in a doubly patriarchal society: deviant because they break the social and gender order through violence in a patriarchal culture and in the criminal organizations constructed, ruled and defined by men.

The two films selected for this discussion are the fictional representations of two godmothers, two real Camorra bosses. The Camorra is one of the most important criminal organizations (i.e. Mafias) in Italy along with the Cosa Nostra (an organization that originated in Sicily), 'Ndragheta (Calabria) and Sacra Corona Unita (Puglia) but also other minor Mafia groups. The Camorra, found in the Neapolitan area, is governed by its own laws and responsible for numerous illicit activities. Historically it had origins as a secret association, founded in Naples between the 16th and 17th centuries but found across Italy by the 19th century. Over time the Camorra has undergone changes and divisions and is made up of numerous clans in competition with each other. La sfida is the story of a young cigarette smuggler, Vito Polara, who in order to boost profits, naively worms his way into a Camorra organization that controls the fruit-and-vegetable traffic from the countryside. Not satisfied with this position, he soon tries to make money by cheating the organization, which leads to his death. His story is accompanied by that of Assunta, a beautiful girl who seduces him and becomes his wife. The film ends with Vito's death on the day of their wedding, while Assunta curses and cries because she would "rather not have a penny but be able to live with her husband”. What really happened was that Pascalone di Nola, a Camorra boss, was killed shortly after his wedding to Assunta 'Pupetta' Maresca. Assunta then killed her husband's murderer to avenge the man she loved. Acts like these acts formed the beginnings of Assunta's career in the Camorra. She would become the boss of Nuova Famiglia (new family)'s clan. However, the film does not include Assunta's decision to kill and enter the criminal ranks.

Il camorrista is a story freely inspired by the book Il camorrista: Vita segreta di don Raffaele Cutolo (The Camorrist: Secret Life of Don Raffaele Cutolo), written by well-known journalist Giuseppe Marrazzo (1984). The book is partly the result of interviews with Raffaele Cutolo, the founder of the Nuova Camorra Organizzata (New Organized Camorra), and to his sister Rosetta, and in part of investigations concerning the milieu Cutolo grew up in. Raffaele Cutolo (played by Ben Gazzara in The Camorrist) founded the new organization 
while in prison because of an altercation that had ended in a murder to defend his sister's honor (who had been groped by a man). The film portrays the very important role played by Donna Rosetta (in the movie Rosaria, she is played by Laura Del Sol) in building the organization in collaboration with her jailed brother.

\section{Power, gender order and crimes}

Power differentials indicate who has the power to define a situation (Goffman, 1961), and one of the mainstays of male domination (Bourdieu, 2002) is violence, which is used to maintain power and supremacy. This is the reason violent behaviour in women is the ultimate challenge to the symbolic order and systems of representation. Media, legal and scientific discourses have always exorcised the trauma produced by violent women, in some cases taking for granted that they were subjugated, or branding them as 'mad' so as to deny their agency or diminish their responsibility (Eastel et al., 2015; Giomi \& Magaraggia, 2017). Or violent women are depicted as 'monsters' (Sjoberg \& Gentry, 2007), thus enveloping them in a demonic 'elsewhere' that serves to mark their distance from 'normal women' (postulated as nonviolent) (Giomi \& Magaraggia, 2017). These are the theoretical beginnings, mainly inscribed in the sociological framework that explains how and why the representations of violent women are changing and whether there is a trend of reinterpretation of gendered dimensions in cinema. This would be a first step in (re)considering the collocation of the media in mirroring, reproducing, and fostering social dynamics related to gender. The study of this process will be done through the lens of violence and crime.

Women have always played an important role in Camorra organizations, even though it is still unclear how often their participation is voluntary or the result of forced integration through family ties (Siebert, 2010). Unlike other Mafia organizations, the Camorra is an urban phenomenon, and there were already famous Camorra women even as early as the 19th century. Take, for example, the Sangiovannara. 'Sangiovannara' is the nickname of a Camorra woman named Marianna De Crescenzo. She was also a pivotal figure in a very important period in the history of Italy: she fought against the Bourbons, according to Mecnikov (Mecnikov cited in Risaliti, 2015). And in September 1860 Giuseppe Garibaldi managed to enter Naples undisturbed thanks to the intervention of the Camorra, headed by Marianna. 
Today, the Camorra is undergoing a major change. There has been an increase in the visibility of women in Mafia organizations in favour of a strong 'feminization', and women are moving from 'gregarious' roles to more roles of leadership on the criminal scene. As Monica Massari writes, 'Rather than changes in the role of women in the Mafia groups, we could talk about changing visibility, or invisibility depending on the historical moments and characteristics of the women included in the various organizations' (2010: 79). With the help of political and legal institutions, the media play a central role in building up and then denying this visibility. Indeed, this new visibility of the Camorra women was somehow 'certified' by their inclusion in Article 416 bis of the Italian Penal Code, which led to a growth in the number of informants and collaborators with the law (Gribaudi \& Marmo, 2010).

\subsection{Steps of analysis}

First, we identify the elements that highlight the 'gendered and gendering dimension(s)' (Buonanno, 2014) in the representation of Pupetta and Rosetta. Secondly, we use Ombretta Ingrasci's categorizations of Mafia women's traditional behaviour norms (2007) to explore how well the two women adhere to these norms. Lastly, we look for other sources responsible for producing different representations, the origins of which lie in sources such as extracts from press articles, and in some cases, also in interrogation extracts and criminal law. We shed light on those ties that could be an important field for further considerations. The first step of analysis is based, then, on the description of La sfida and shadowing, the critical works on these movies and on a careful study of gender stereotypes. Secondly we look to the aforementioned traditional roles played by women in Mafia organizations: the maternal role, the commitment to transmitting the cultural code, the incitement to revenge, the surveillance of their reputation and their commodification of marriage policies - and how Pupetta's and Rosaria's representations figure into this. The text continues with the analysis through a reading of how Maresca and Cutolo were portrayed in the press. Articles on Maresca's case consist of secondary data, collected by Marcella Marmo's research (2010) on media descriptions of her first trial. In Rosetta Cutolo's case, in addition to the book by Giuseppe Marrazzo and his interview with RAI, we analyse the news media, specifically La Stampa, Il Messaggero, la Repubblica, Il Manifesto and L'Unità. We have selected for each newspaper the news coverage of Rosetta on the day after her arrest in 1993 (or the first day news about her was given in that specific newspaper). We also propose a few theories on what happened with the passing of Article 416-bis/1982 of the Italian penal code, and, consequently, with the growth in the number of pentiti (informants; justice collaborators) (Gribaudi \& Marmo, 2010).

Perspectivas de la Comunicación - Vol. 14 - No 2 - 2021 - pp. 31-56

Universidad de la Frontera - Chile 


\section{Questioning gender. Differences and similarities of two Camorra stories}

In this article, we form our argument around two central authors to see how these two films we analyze and compare are treated in the literature: Gian Piero Brunetta (2007, 2009a, 2009b) and Laura, Luisa and Morando Morandini, (2017). We compare two 'experimental' films, in the sense that La sfida and Il camorrista are both made by filmmakers at the start of their careers. These two films depict very different periods: La sfida was screened at the end of the 1950s, and Il camorrista is from the 1980s, but they share similar qualities. For instance, Morandini defines La sfida as a film 'between the Hollywood action film and the Camorra political analysis film' (Morandini, Morandini \& Morandini, 2017: 1380) and Il camorrista as being 'between American action cinema and the Neapolitan drama' (Morandini, Morandini \& Morandini, 2017: 232). Both screenplays are based on real events. With La sfida, Rosi delved into neorealist cultural theory and began to explore historical facts and to investigate 'the cultural world that lies behind them' (Gili 1976 cited in Brunetta, 2009b:147).

\subsection{La sfida}

Brunetta describes La sfida as a work rooted in a true-life episode from the 'Neapolitan underworld: the wife of a small guappo (bully and camorrist) takes revenge for the killing of her husband on their wedding day, by in turn killing his killer' (2009b: 146). The avenging woman was Assunta Maresca. She would later stand trial for murder and other crimes. Brunetta goes on to assert that 'for over 30 years Francesco Rosi's cinema has been a continuous glance in which some aspects of Italian reality and history are repeatedly and periodically placed at the centre of the focus [...]. Rosi is one of the few post-WWII Italian filmmakers with a panoramic look and a capacity for variable focusing of near and far, which allows him to embrace more phenomena and observe recursivity and spatio-temporal metamorphosis, to hypothesize causes and consequences' (Brunetta, 2009b: 145).

Unlike Brunetta's description, Francesco Rosi's Assunta in La sfida is an attractive, naive young lady who does not want to be involved with the Camorra. Rosi ended the story before Assunta's act of revenge because her trial had not been held yet. However, the temperament of Rosi's fictional character was very different from the real 'Pupetta': a young woman ready to kill for her love and who was undergoing the process of becoming a Camorra boss. Her true temperament was, for that time, a dangerous challenge to gender norms and therefore not acceptable. As aggression and violence served as the fundamental dividing point between masculinity and femininity (Jack, 2001: 30), female violence and violent women 
were, and still are, destabilizing figures. They unsettle normative gender constructions and damage the binary assumptions of the gender system, where violence is thought to be solely the domain of males. Rosi preferred not to get involved in representing a violent female character primarily because Italian society in the 1960s was not ready to accept such representations. Rosi adopted the heterosexual 'male gaze' which determines women's lack of agency, subordinated identity, and male objectification of women (Mulvey, 1975).

In 1958, the attempt to present a harmless Pupetta to preserve society's gender structures was achieved through specific choices of additions and cuts, extreme close-ups, as well as through the coordination of storyline and narrative techniques. Although the real Pupetta Maresca was a prize-winningly beautiful woman, Rosi's choice to describe her as a languorous, underage woman who used sensual techniques to fascinate both Vito, and in a larger sense, the movie audience, was an admitted underestimation of Pupetta's power. Rosi's representation is completely in line with Mulvey's thought and Van Zoonen's (2011: 87) affirmation: 'In western societies to be looked at is the fate of women, while the act of looking is reserved to men'. And this gendered glance at the figure of Assunta Maresca is rendered through extreme close-ups of Rosanna Schiaffino's beautiful face and her explicit invitations, always through her eyes, to look at her wonderful body. Her voice was also a tool of male attraction: she guided Vito to the roof with her sensual song.

In adherence to the conservation of gender order, her seductive behaviour-the only evidence of a kind of autonomous self-identification-suddenly became moderate, gentle, sweet, and servile behaviour when she became Vito's fiancée. The extreme close-ups that at the beginning of the movie emphasized her sensuality did not diminish as the movie progressed; however, by the end of the film, she was depicted as a candid and worried beauty. Assunta Maresca's grit had gone, along with one of the Mafia women's traditional roles: that of revenge. Instead of introducing what happened after Vito's death, namely, Pupetta's killing of the man who murdered her husband, Rosi chose to deny Assunta's belonging to and approval of the Camorra organization. The movie ends with Assunta's own words, saying that she was not interested in money or business but that she only wanted to stay with her beloved husband. In 1958 Rosi then decided to cut some elements from the story: for instance, the element of homicidal revenge. He did this first because Pupetta was not yet on trial, and because the sensual, loving, sad and poetic elements fit the female gender stereotype. 


\subsection{Il camorrista}

According to Brunetta (2007), Il camorrista is 'a strange debut'. It cost more than five billion liras, was produced with Goffredo Lombardo, and distributed by Titanus and ReteItalia. Tornatore's experience as documentary director and his 'free' adaptation of Marrazzo's novel about Raffaele Cutolo probably convinced the producers to invest in the film. Il camorrista features another woman in a central role: Rosaria, the 'Professor's sister'. However, the importance of her role is not emphasized by either Brunetta or Morandini. Tornatore portrays a reserved Rosetta Cutolo (aka Rosaria), minimizing her agency, i.e. belittling her determination, capacity, and power to take decisions. She was at the height of her powers in the 1980 s and, when she was arrested in 1993, she was recognized as a very strategic, cynical, and intelligent woman who oversaw many murders. She was the administrator of the entire Nuova Camorra Organizzata and had close contacts with local and national politicians.

Rosaria's role underwent a gendering in Tornatore's depiction, although he could not (and hopefully did not want to) deny a truth already described in Giuseppe Marrazzo's book, which the movie was based on. And, in fact, Tornatore also made an attempt at de-gendering Rosaria. In Il camorrista, Rosaria is shown as a nice girl, whose grace is emphasized through the choice of a charismatic actress, Laura Del Sol, and through the use of close-ups which also underscore both her simplicity and her refinement: her head is held high but her eyes look downward; her curly hair is always well coiffed; she only wears soft makeup and moves slowly and calmly. A more contained femininity and a more reserved woman fit the traditional characteristics of the female protagonist. Although Rosetta Cutolo was dubbed the 'red primrose' of the Camorra, Tornatore chose to present us with a quiet, mildmannered woman that ruled the Camorra for 30 years.

We notice that Tornatore perpetuates and reinforces gender norms using at least four strategies: first of all, as previously stated, there are the close-ups that show vulnerability, which meet Boyle's (2005) definition of what femininity should be: '[femininity is] associated with nurturing and caring for others, with emotion, passivity and vulnerability' and also aligning with the Mafia women's traditional roles. Also, for Judith Butler, vulnerabilisation is a process generating 'precarity', and therefore dependency (Butler, 2011, Casalini, 2016), quoting 'pathogenic vulnerability' (Mackenzie, 2014), writes that it is a socially induced process to maintain the current hierarchies of power. The second strategy is, again, romantic love. Near the end of this long film, O' Professore orders Rosaria to kill Ciro, his childhood friend. It is then that she has difficulty accepting that order, because, 
according to the movie, she had been secretly in love with Ciro for many years. For that reason, 'O'Professore advises her 'to reason with her head not with her heart'. Thirdly, she executes her brother's orders but does not like instigating murders, and she always asks her brother to act for good and not for evil. And lastly, there is a final venting of emotion where she complains to her brother about having dedicated her life to him and never having carved out a niche for herself. These are all gendering expedients and alterations of the real facts. We are not able to say whether she was a quiet woman, but what is certain is that she was strong enough to build a new Camorra organization. Here the gendering dimension is constructed by adding Rosaria's love for Raffaele's best friend, which is a fictional event introduced by the film and featured in one of the final scenes, which shows her being exploited by her brother.

Tornatore shows at least four 'de-gendering' characteristics. A more general de-gendering is expressed by how Rosaria commands the men and organizes the Nuova Camorra Organizzata on a large scale. A second example shows Rosaria taking part in important meetings and making decisions that she knows her brother would accept. Third, she herself orders the murder of a paedophile living in her area, whose young victim had asked for her help. She had the man killed without asking for her brother's permission. And fourth, she kisses Ciro before seeing him explode in his car and letting his lover sink into acid.

By 1986, the overturning has already begun, and Rosaria seemed both content and cynical at the same time. Many things had happened during these 30 years. In terms of societal changes, we can remember at least two important ones: women's emancipation and the Mafia's adaptation to new illicit markets. The first change may have called into question traditional male security and traditional male notions of women's unreliability.

\section{Questioning gender: Pupetta and Rosaria in the light of traditional Mafia gender norms}

Comparing the lifestyles of the two 'real' ladies we can observe that their representations tend to diminish their agency as a direct result of the effects of gendered strategies of representation. A closer observation of Pupetta and Rosaria through Ombretta Ingrasci's traditional Mafia gender norms categorization can help us better understand slight differences in their gender expectations, especially in Rosaria's case. 
According to Ingrasci, traditional women's roles in the Mafia are maternal ones, in line with transmission of the cultural code, protecting reputations and managing marriage policies. We noticed how those norms are mainly related to the domestic domain and inscribed into the relational dimension. Also, in the case of feminine roles, a common Mafia value is that of honor, here identifiable as protecting one's reputation and directly linked to marriage policies and to obligations of revenge.

The vision of La sfida suggests that although Pupetta is not (yet) a mother in the movie, at the beginning of the story she plays the role of the seductive girl who wanted to be seen and taken by the local young boss. But as soon as she becomes Vito's girlfriend, waiting to be officially engaged, she starts looking after him in a very maternal way. The other traditional trait she exhibits is a willingness to preserve the man's reputation, both with her change in behaviour (becoming the ideal sweet, innocent girl) and in defending her future husband from gossip, making him reflect before making decisions and advising him in his choices. Of course, these two characteristics were not at all observed in Vito, who is represented as very assertive, independent from her judgment and capable of doing everything by himself. These same behavioural traits are also seen in Vito's mother, who plays the traditional women's role albeit with little awareness of her son's business. She adheres to all the traditional Mafia roles, including that of marriage policymaker, since she hints at whether she thinks Assunta is the right wife for Vito, as she was 'shameless' when she had lured him to a terrace far enough away to remain alone with him.

Rosaria was not a mother either but Raffaele's older sister, and she was also the reason why he got sent to prison. So, she played a responsible maternal role for her brother, who displayed a volatile personality with sudden mood swings which she tried to contain by speaking calmly and meeting his needs and requirements. Although she did not have any children, as she was 'the boss' outside the jail, she was naturally active in publicising the Nuova Camorra Organizzata's cultural code throughout the community (carrying out her brother's role) and also giving him the information he needed to decide what kind of revenge to take on his foes. At the same time, she did not only look out for her brother's reputation but also helped construct it. Although she is not so openly active in enforcing marriage policies, she was the one who set up the meeting between O'Professore and his future wife. So, Rosaria is in some ways living up to the traditional Camorra gender role expectations for women. We should not forget that the filmic representation presents us a sweet, shy, languid 
young lady who, despite her appearance as being calm and reassured has empowered and expanded her brother's reign.

Compared to Maresca's filmic depiction, entirely based on adherence to gender norms and (especially after the marriage) to the Mafia gender norms, Rosetta's agency is undeniable: she is not the boss, but she does act like one. She is a sophisticated strategist, and in some cases, she is forced to make fatal decisions.

These gender norms are closely related to issues of women's empowerment. Both movies (the first one more than the second) belong to a period when Mafia's and the Camorra's inner workings of power were almost completely unknown. Also, the differences between Mafia families were not so well defined, which might go a long way to explaining the choices of the two film directors: they decided to adhere to general Mafia norms and not distinguishing Mafia norms from those of the Camorra. Whatever the case may be, even in 2007, Ingrasci's categorisation portrays the female figure in a servile position to male power, although questioning whether these women's conditions could soon experience a sort of evolution. Ingrasci refers also to the (pseudo)emancipation of women Mafia bosses, wondering if they are completely aware of their being regents (of their men's realm) and not queens. Women are actually very active in Camorra organisations and, even though their visibility is limited, they are listened to in important secret meetings. Often, they organize and run such meetings.

\section{Questioning gender: Pupetta and Rosetta in the press}

Passion, drama and, eventually, murder for love: this was the press media's narrative framing of Pupetta's trial. The trial began in 1959 and garnered remarkable press coverage. News reports emphasized Pupetta's beauty and her sensibility, and the press met with many difficulties in manipulating Assunta's temperament to align with female gender expectations. La Stampa, Roma, Corriere della Sera were the three newspapers analysed by Marcella Marmo in her work. She used these as secondary sources, reporting and reinterpreting them in a useful account of how the press media covered the trial. It was found that these newspapers still maintained the trend of objectification of Assunta's body and the minimalization of her criminal traits. We use Marmo's trial analysis to underline evidence of male bias in these journalistic reports. Marmo speaks about a double register of the Maresca trial media narratives 'between the reasons of sentiment and those of calculated interest' (Marmo, 2010: 129). Pupetta's beauty did not go unnoticed by the press; indeed, 
her beauty was often the focal point from which a number of assumptions about the trial begin: 'in the expressive southern face the eyes are bright, very dark, daring, and a wave of brown hair, with golden reflections, went down to cover the shoulders' (Corriere della Sera, 1 April 1959, in Marmo, 2010).

The press liked the romantic version of the 'crime for love', since this correlates with what patriarchal society asks of a young woman: absolute loyalty to her man. On the contrary, the press considers some of Maresca's attitudes unpardonable: 'what is missing from Pupetta Maresca [...] is the sacrifice, missing a crown of thorns. Too well-combed hair; she lacks a handful of ashes on those too shiny hairs. Bear her punishment, serious or light' (Roma 8 April 1959, in Marmo, 2010). Being a woman means showing feminine weakness: a wild nature is not proper for a woman. But Pupetta is not weak at all: 'the microphone has exaggerated her sobs [...]. A matter of very few minutes and soon the lost crying girl returned the queen of the "guappi"” (Corriere della Sera, 5 April 1959, in Marmo, 2010).

The press also hunts for the 'real woman', the one that properly adheres to female gender expectations: 'Pupetta Maresca has resisted well the rhythm of the questions, but has had more than a failure, more than a contradiction. A couple of times she brought the handkerchief to her eyes and if she was crying, if it was a sign of feminine weakness, it could be considered a consoling revelation. In this indomitable creature, in this stubborn avenging being, the woman was finally discovered' (La Stampa, 4 April 1959, in Marmo, 2010). Both the press and the film industry had a hard time putting this gender-norm-challenging lady in an acceptable patriarchal frame. But they succeeded.

After almost 30 years something had finally changed. Rosetta Cutolo arrived late in the newspapers and in journalistic information. In 1981 Marrazzo interviewed her in a RAI program dedicated to her brother (https://www.youtube.com/watch?v=djU_eT1fSOU). In the interview Marrazzo calls her 'Miss Cutolo, embroiderer and responsible for all the promotional activities of her brother'. He asked her, however, if she was the one who kept the contacts for her brother. She serenely explained that she did not hold any contact but that she kept guaranteeing favours to the people Raffaele had named. She said that 'Raffaele only does good things and is a good boy (nu bravo guaglione)'. When Marrazzo stated: 'they say that your brother is the head of the Camorra', she replied 'I do not understand anything about these things'. Marrazzo's book first illustrates the figure and the role of Rosetta Cutolo 
and, although until 1993 her name remained ancillary, his work already focused the attention on this Camorra woman's role.

Apart from Marazzo's book, the figure of Rosetta was ignored by the press at least until 1993, when she turned herself over to the police. 'I am (Rosetta), and burst into tears' is announced on la Repubblica. Most of the newspaper headlines had similar wording in reporting her arrest: Rosetta Cutolo 'arrested in her house', '(super) fugitive Rosetta Cutolo arrested after 12 years absconded'. They used her nicknames: 'the chatelaine' (since she lived in the Medici castle of Ottaviano) (Cavalieri, 1993) or 'iced eyes' (Vasile, 1993), due to the light blue colour of her eyes. Often newspapers also referred that she sacrificed her love life to Raffaele.

On the front page la Repubblica describes Rosetta as 'the "Pimpernel" of the Camorra' (Cervasio, 1993). The front page of Il Messaggero gives news of Rosetta's surrender and writes in a short article: '[...] the (super)fugitive, number one of the Camorra [...]. The sister of "don Raffaele" considered to be the head of the New Organized Camorra' (Di Giovacchino \& Di Dio, 1993), and on page 3, there is an article titled "We help poor people". So Cutolo's sister explained the activities that she organized' (Di Dio, 1993). We read that '[she is] considered the brain of the clan [...] family-head since she was seventeen, she had left his boyfriend to take care of the younger brothers' (Di Giovacchino, 1993). Il Manifesto presents an article on the fourth page where we find in a highlighted paragraph: 'For the magistrates [she is] the depositary of the Nuova Camorra Organizzata secrets' (Pastore, 1993). L'Unità gives ample space to the story and writes on page 8: '[she] has directed the New Camorra for over a decade' (Faenza \& Vasile, 1993). And with this, the media narrative had changed. A (female) boss was born. She is now considered to be number-one boss of the Nuova Camorra Organizzata, the brain trust of the clan and the depositary of the Nuova Camorra Organizzata secrets. And L'Unità reserves a space for women bosses, Pupetta and Rosetta along with other mafia women (Faenza, 1993).

\section{Media spotlights on other male domains}

On September 13th, 1982, the Rognoni- La Torre law was approved, and through the socalled pentiti (justice collaborators) revealed the dynamics of Mafia organisations. The pentiti uncovered Mafia rules and codes and shined a light on the kind of commitment and responsibilities women had: those stories became part of wider news media investigations. As Maria Teresa Principato said during an interview on Voci del Mattino (Morning Voices), Radio1 RAI, when talking about Cosa Nostra and the effects of art. 416 bis: 'for a long time 
the role of Mafia women was neglected by the judges. Suffice it to say that the first sentence that recognized a woman guilty of Mafia association is a sentence from the Court of Cassation in 2007, therefore very recently. Before, women were covered by impunity because they could not be 'bad' and could not self-determine [...], therefore, they could not be guilty and their conduct, albeit criminal, was covered by immunity (from prosecution)'.

What had been invisible was becoming visible - and slowly became fictionalised. If we compare Tornatore's work to what had gone before, referring to the Principato quote, even though his work was only belatedly appreciated, it was a pioneering product, resulting from investigation and the new definition of what was legal and illegal. And his work on the figure of Rosaria/Rosetta is extremely valuable. Rosetta was an invisible woman, despite being extremely powerful. The same invisibility is often still conferred on real Camorra women.

It is worth remembering that the law is a patriarchal, male domain. This explains why, even though women's roles in the Mafia became much more exposed, women Mafiosi were not persecuted for years, a fact that surely aided the Mafia's survival. Women gradually became indictable for being Mafia bosses or members. Starting from the Rognoni-La Torre law, these women became part of Mafia narratives, in both journalistic and cinematic mediums, and then they became just as indictable for their crimes as men were.

In 2005 Saviano shed light on how Camorra women are quite resourceful and firmly committed to protecting and advancing the organisation's interests and their secret rules (2005). He wrote in Manager in rosa, matriarcato della Camorra (Manager in pink, matriarch of the Camorra) that not one woman collaborated with the authorities and that many of them blamed their men: fathers or brothers who were 'infamous' for being pentiti. Secondly, the new market, far from Vito's fruit and vegetable stall, was that of narcotrafficking and illegal assets, where women have the advantage of being less recognisable.

\section{Iridescent lights on Godmothers: From invisibility to visibility}

The only perspective that will always be with us is that of the male gaze, which, in various manifestations of Bourdieusian memory, demands a discourse on the representations of our two cynical godmothers and their femininity (Bourdieu, 2002) and thus submission to the gendered order. Assunta is 'just' the ideal type of female identity in a traditional gender order, and Rosaria is the result of a continuous balancing act between keeping and challenging gender order, confirming the gender-related and de-gendering characteristics 
of her figure. There are many reasons for this late acceptance of a definitive female role in these organisations. Some of them have already been mentioned in this study. Between the lines we can also glimpse the way in which the world of the Mafia and the Camorra is discursively built around male domination and masculinity. Siebert talks about a male/masculine chirality where males are the ones that control women according to male needs (2010). And to analyse the Camorra through our texts is to analyse them through a male gaze: directors, journalists, lawyers; they are all males, or, in any case, they preside over a patriarchal environment and are reinforcing male power. Therefore, both the sources and the 'gazes' are strongly determined by the male gender.

La sfida and Il camorrista are thus important because they trace a path that recognises a small shift in the definition of gender and in relation to shifting gender-related powers. While Assunta's behaviour completely fits within the confines of gender expectations, despite acting seductively toward Vito (i.e. an 'active' adhesion to the female destiny of being objectified by the male gaze as Mulvey affirms), Rosaria shows at least four kinds of deviance from scripted gender behaviour: she is a both woman and commander-in-chief of the Nuova Camorra Organizzata. She is accepted in male decision-making circles. She is also a resolute woman, ordering a fatal hit job on a man. And she deviates from traditional gender expectations while 'taking' (i.e. kissing) the man she loved before killing him - like a praying mantis. It is no secret that this female power already existed in the Camorra. If we quickly glance at Assunta Maresca's biography, which is full of revealing details because of her frequent appearances in the media, we find a powerful woman who only maintains her gender inscription - her beauty for instance - because it gives her certain advantages. Her image plays into a sort of romantic myth because she killed for love. But she also killed - or she ordered and threatened to kill - to empower her organisation. If we read the deeds of Sangiovannara (Marianna de Crescenzo), also involved in the unification of Italy, we see that in the Camorra there has always been a place where power can be 'pink'. These strong antiheroines exploited their invisibility, not initiated, and not listed in the Camorra's ranks, to make it a space for developing their power.

But these two films tell us that in 1958 it was not yet possible to popularise discourses on the power of women in the Camorra because not only was the Camorra a patriarchal organisation (which some authors, however, also deemed to be false), but the other areas where culture was produced - journalism and law at least - were defined by a very strong patriarchal essence. The emancipation movement, women's access to university education, 
even those courses normally considered to be for men, such as law, for instance, meant that the opaque reality gradually became more readable and visible, the weaker voices became more clearly audible, and a different world presented itself. Therefore, it was also portrayed through cinematic representations. And in 1986 some of the Camorra women's features became more visible. What had been invisible became visible. And the engagement of cinematic production with the true situation was on its way to being achieved. And visibility through cinematic production means being seen by a very large audience.

\section{Iridescent lights on Godmothers: from visibility to invisibility?}

This article has discussed the increasing acceptance of the idea that women can enter the classically masculine field of violence and crime. This contribution, therefore, has given us the chance to see how the process of changing a social order, or stereotype, is complicated and subject to various influences from a myriad of social fields. The article has also highlighted how media representations often reflect the dominant ideology (Hall, 1980) and hence contribute to maintaining social hierarchies using stereotyped images; at the same time, the mass media is able to work toward changing these stereotyped visions, interrogating them and making them visible to the public at large. This is a process that shifts the power of the media from the ideal of mirroring reality to that of being commentators on and producers of reality. And this shows the importance of studying the iridescent gender question through media representations: what is visible today could become invisible tomorrow.

In recent TV series Camorra women can challenge the dominant, masculine antihero trope (Buonanno, 2017). Think of the female bosses of Gomorra. They are visible, powerful, they substitute their men because they can really be like men's worst stereotyped representations: bad, cynical, and emotionally neutral (in 'rare' moments even acting badly towards their children). They can be bosses and powerful godmothers. This is how they are portrayed: with no regard for the gender order. These fascinating women take us into violent worlds and show us their codes (which they share with men). And they fascinate audiences that, according to Neroni 'on the one hand (...) want to preserve our society against the threat of violent women, but, on the other hand, the threat excites us because it involves overturning

the ideological structures (most especially those involving gender) that regulate our experience' (2012). 
Those fascinated audiences could also be partly dazzled by those violent ladies and could forget their involvement in overturning ideological gender structures. The inherent risk is to see them as strong as men, depicted through violent and dangerous stereotypes normally associated with men. Amused by their cynicism and their bad behaviour, we may risk restricting these women to another narrow category: women who are as violent as men. Again, not these are not 'proper' women but women as a distorted gendered representation of men.

\section{Conclusions: two criminal women between genderization and de- genderization}

In this study we have highlighted a path of construction of gender representations that, completely or partially, correspond to traditional gender norms and, more specifically, to the gender norms of Mafia organisations.

We did it by analysing the filmic representations of two real-life women, Assunta Maresca and Rosaria Cutolo, complementing the analysis with other materials that could help us better understand the real people that the two characters were based on and how they adhered to certain rules of behaviour in the Camorra organisations. Also, with these materials we can get a better idea of the information disseminated to the general public by the press and their legal/procedural position.

The analysis of filmic texts, i.e. the analysis extended to these various materials, led us first of all to recognise that the links between media and tradition and media and gender are strong, where the former link, especially in the past, has helped strengthen the latter.

The choice to study Assunta and Rosaria, both "bad" antiheroines in real life, shed light on the way in which the filmic representation emphasised or ignored (or at least made less visible) these doubly deviant aspects of the two women: deviant as criminals and deviant as women among criminal males. The two women, in fact, in real life have challenged a double trope: that of the good, loving, and passive woman and that of violence as an exclusively male domain.

But this study's argument suggests that (albeit with great difficulty) given the personalities of those delinquent women, the two directors, and the media in general have worked hard 
to mould the lives of these two women as a response to female role expectations. Two women forced to live their lives in a de-gendered way have been re-genderized by the media.

This re-genderization is clear in the first film, La sfida, for various reasons. Pupetta's trial is still to be held, female emancipation is far off in the future, there is very little knowledge of the Camorra phenomenon, and an Italian society depicted in the film where gender roles were very distinct. In fact, the film version of Pupetta conforms to the norms of that particular genre: she is beautiful, sweet and romantic. While the popular media narratives of the real 'Pupetta', Assunta Maresca, also depicted her in this way, even the following year when she was on trial for the murder of her husband's killer. A former miss could not be such a dangerous woman.

However, Tornatore's Il camorrista is less clear-cut on this issue. The film is a more complex work, somewhere between genderization and de-genderization. And it could not have been otherwise, precisely because of what this study observes in the other materials such as the Rognoni-La Torre Law with article 461 bis on pentiti.

The fundamental glue of all mafia organisations, namely the omertà (silence) code - aimed at covering up criminal conduct, concealing the identity of the person who committed a crime (or in any case keeping silent about circumstances useful for the investigation of the judicial authority) - was no longer respected.

Once pentiti spoke out, women's roles in Mafia organisations began to emerge. And journalists spoke to the public at large. Here we note the work of Marrazzo, who in 1981 interviewed Rosetta for RAI. He helps shape Rosetta's identity by defining her as: 'Miss Cutolo, embroiderer and responsible for all the promotional activities of her brother'. Tornatore depicted a more complex figure; he does not hesitate to emphasise the typical feminine traits in line with traditional expectations and, also, to exaggerate them with respect to those found in the character and appearance of Rosetta. But he also depicts gestures and choices that do not fit with traditional gender descriptions.

In 1993 Rosetta was arrested. By then, everyone knew who the 'red primrose' of the Camorra was. She did not break down, cry, nor speak. She surrenders herself to justice coolly and calmly. And that time the press reported Rosetta's role without emphasising gender and without adding romantic embellishments aimed at diminishing her power. This kind of 
journalistic narrative is a far cry from the way journalists depicted Pupetta: as a woman without agency.

And so, the overall story of Mafia women begins to be freed from gender constraint. Doubts remain about women's roles as 'regent' and not 'queens' of the kingdom of the Mafia. Academic literature discusses the pseudo-emancipation of women but also of the growing centrality of their role. Questions are about their spontaneous or obligatory decision to act as 'mafiose' (Ingrascì, 2007; Siebert, 2010). But there is no doubt that this feminine role is very far from the description intended for Maresca in the late 1950s.

This study aims to be both a reflection and a challenge. For example, it might inspire scholars to delve deeper into the relationship between journalistic representation and film production. It will be even more interesting, through careful collaboration between media scholars and law scholars, to observe how the approval of an important and innovative law (in this specific case art, 416bis) modifies the way in which information is made and public discourse is built on specific phenomena.

\section{Conflicto de interés}

Las autoras declaran que no tienen conflicto de interés. 


\section{Referencias bibliográficas}

ALBERONI, F. (1979): Innamoramento e amore. Milano, Garzanti, 1979.

BARBAGLI, M. \& MINELLO, A. (2018): Quando a uccidere sono le donne. lavoce.info. Retrieved September 25, 2020, from http://www.lavoce.info/archives/50539/aduccidere-le-donne

BOURDIEU, P. (2002): Masculine Domination. Stanford, Stanford University Press.

BOYLE, K. (2005): Media and Violence: Gendering the Debates. London, Sage.

BRUNETTA, G. P. (2007): Il cinema italiano. Da La dolce vita a Centochiodi. Roma-Bari, Laterza.

BRUNETTA, G. P. (2009a): Il cinema neorealista italiano. Storia economica, politica, culturale. Roma-Bari, Laterza.

BRUNETTA, G. P. (2009b): Il cinema neorealista italiano. Da Roma città aperta a I soliti ignoti. Roma-Bari, Laterza.

BUONANNO, M. (2014): Gender and media studies: progress and challenge in a vibrant research field. Anàlisi. Quaderns de Comunicació i Cultura, no. 50, pp. 5-25. https://doi.org/10.7238/a.voi50.2315

BUONANNO, M. (2017): Godmothers in Italian Mafia Story: Or "Something else besides a Mother”, in M. BUONANNO (Ed.), Television antiheroines. Women behaving badly in crime and prison drama (pp. 27-48). Bristol, Intellect.

BUTLER, J. (2011): Bodies That Matter: On the Discursive Limits of 'Sex'. New York, Routledge.

CASALINI, B. (2016): Politics, Justice, and the vulnerable subject: the contribution of feminist thought. Gênero \& Direito, 5(3), pp. 15-29. 
CAVALIERI, M. (1993, February 9th); 'Così la ‘castellana' per seguire il suo fratello rinunciò all'amore'. La Repubblica.

CERVASIO, S. (1993, February 9th): 'La resa di Rosetta Cutolo’. La Repubblica.

DI DIO, G. (1993, February 9th): 'Noi aiutiamo la povera gente'. Il Messaggero.

DI GIOVACCHINO, R. \& DI DIO, G. (1993, February 9th): 'Presa Rosetta, latitante in casa'. Il Messaggero.

DI GIOVACCHINO, R. (1993, February 9th): 'Arrestata Rosetta, latitante in casa'. Il Messaggero.

EASTEL, P., BURTELS, L., NELSON, N. \& HOLLAND, K. (2015): How are women who killed portrayed in newspaper media? Connections with social values and the legal system. Women's Studies International Forum, v. 51, pp. 31-41.

FAENZA, V. (1993, February 9th): 'Rosetta Cutolo, una resa condizionata'. L'Unità.

FAENZA. V. \& VASILE, V. (1993, February 9th): 'Rosetta Cutolo catturata dopo 12 anni'. L'Unità.

GIDDENS, A. (1990): The Consequences of Modernity. Cambridge, Polity Press.

GIOMI, E. \& MAGARAGGIA, S. (2017): Relazioni brutali. Genere e violenza nella cultura mediale. Bologna, Il Mulino.

GOFFMAN, E. (1961): Asylums. Essays on the social situation of mental patients and other inmates. New York, Anchor Books.

GRIBAUDI, G. \& MARMO, M. (2010): Che differenza fa? Meridiana. Rivista di Storia e Scienze Sociali, no. 67, pp. 9-19.

HALL, S. (1980): Cultural Studies. Two paradigms. Media, Culture and Society, 2(1), pp. 5772. 
INGRASCÌ, O. (2007): Donne d'onore, Storie di mafia al femminile. Milano, Bruno Mondadori.

JACK, D. C. (2001): Behind the Mask. Destruction and Creativity in Women's Aggression. Harvard, Harvard University Press.

JEWKES, Y. (2011): Media and Crime: Key Approaches to Criminology. London, Sage Publications.

MACKENZIE, C. (2014): The Importance of Relational Autonomy and Capabilities of an Ethics of Vulnerability, in MACKENZIE, ROGERS \& DODDS (Eds.), Vulnerability: New Essays in Ethics and Feminist Philosophy (pp. 33-59). Oxford: Oxford University Press.

MARMO, M. (2010): La rima amore/onore di Pupetta Maresca. Una primadonna nella camorra degli anni cinquanta. Meridiana. Rivista di Storia e Scienze Sociali, no. 67, pp. 113-143.

MASSARI, M. (2010): È la giustizia che mette in mezzo le donne»: il carcere, la mafia, le donne. Meridiana. Rivista di Storia e Scienze Sociali, no. 67, pp. 79-94.

MORANDINI, L., MORANDINI, L. \& MORANDINI, M. (2017): Il Morandini 2018. Dizionario dei film e delle serie televisive. Bologna, Zanichelli.

MORRISSEY, B. (2003): When Women Kill: Questions of Agency and Subjectivity. New York, Routledge.

MULVEY, L. (1975): Visual Pleasure and Narrative Cinema. Screen, 16(3), pp. 6-18.

NEGRA, D. \& LAGERWEY, J. (2017): 'Introduction', in M. Buonanno (Ed.), Television antiheroines. Women behaving badly in crime and prison drama (pp. ix-xvi). Bristol, Intellect. 
NERONI, H. (2012): Violent Woman: The Femininity, Narrative, and Violence in Contemporary. New York, State University of New York Press.

O’NEILL, M. \& SEAL, L. (2012): Transgressive Imaginations: Crime, Deviance and Culture. New York, Palgrave Macmillan.

PASTORE, A. (February 9th): 'Arrestata Rosetta Cutolo, da 12 anni latitante in casa' (p. 4), Il Manifesto.

RISALITI, R. (2015): Corrispondenze dall'Italia risorgimentale di Lev Il'ic Mecnikov. Moncalieri, CIRVI.

SAVIANO, R. (2005): Manager in rosa, matriarcato della camorra. Retrieved August 25, 2020, from http://archive.li/PKrcz

SEAL, L. (2010): Women, Murder and Femininity: Gender Representations of Women Who Kill. New York, Palgrave Macmillan.

SIEBERT, R. (2010): Tendenze e prospettive. Meridiana. Rivista di Storia e Scienze Sociali, no. 67 , pp. 21-33.

SJOBERG, L. \& GENTRY, C. (2007): Mothers, Monsters, Whores: Women's Violence in Global Politic. London, Zed Books.

THOMPSON, J. B. (1995): The Media and Modernity. Stanford, Stanford University Press.

VASILE, V. (1993, February 9th): 'Donna dagli occhi di ghiaccio. Sa tutto sul "caso Cirillo"' (p. 8), L'Unità.

ZOONEN, L. (2011): Preface, in T. KRUNEN, C. ALVARES \& S. VAN BAUWEL (Eds.), Gendered transformation. Theories and practices on gender and media (pp. 1-6). Bristol, Intellect. 


\section{Audiovisual contents}

Marrazzo, G. Dossier Camorra, RAI / Radio Televisione Italiana. [Retrieved August 1st, 2018, from (https://www.raiplay.it/video/2016/08/watchfolder-D8508-Tg2-DossierCamorra-20160816152548--BR--180omp4-bobdb924-e532-494f-9b415eb5ebo04a58.html]

The good, the bad and the ugly [Retrieved September 1st, 2020, from https://www.youtube.com/watch?v=djU eT1fSOU] 